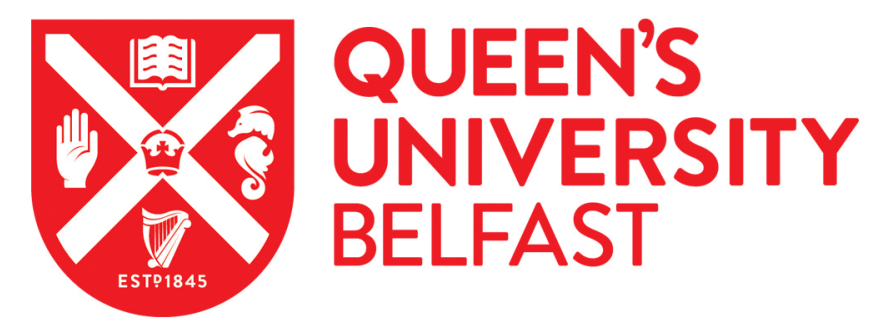

\title{
Vaccinate boys as well as girls against HPV: it works, and it may be cost effective
}

Prue, G. (2014). Vaccinate boys as well as girls against HPV: it works, and it may be cost effective. BMJ, 349, [g4834]. https://doi.org/10.1136/bmj.g4834

\author{
Published in: \\ BMJ
}

Document Version:

Publisher's PDF, also known as Version of record

Queen's University Belfast - Research Portal:

Link to publication record in Queen's University Belfast Research Portal

\section{Publisher rights}

() The Authors \& BMJ Publishing Group Ltd 2014

This is an open access Creative Commons Attribution-NonCommercial License (https://creativecommons.org/licenses/by-nc/4.0/), which permits use, distribution and reproduction for non-commercial purposes, provided the author and source are cited.

\section{General rights}

Copyright for the publications made accessible via the Queen's University Belfast Research Portal is retained by the author(s) and / or other copyright owners and it is a condition of accessing these publications that users recognise and abide by the legal requirements associated with these rights.

\section{Take down policy}

The Research Portal is Queen's institutional repository that provides access to Queen's research output. Every effort has been made to ensure that content in the Research Portal does not infringe any person's rights, or applicable UK laws. If you discover content in the Research Portal that you believe breaches copyright or violates any law, please contact openaccess@qub.ac.uk. 


\title{
VIEWS \& REVIEWS
}

\section{Vaccinate boys as well as girls against HPV: it works, and it may be cost effective}

\author{
Protecting boys as well as girls by vaccinating against human papillomavirus may cut the incidence \\ of genital warts and several cancers among both sexes, writes Gillian Prue
}

\author{
Gillian Prue lecturer in chronic illness, School of Nursing and Midwifery, Queen's University Belfast, \\ Belfast BT9 7BL
}

Human papillomavirus (HPV) infection is common in men. Many of these infections are transient and clinically insignificant, but persistent infection with HPV types 6 and 11 can lead to genital warts, and oncogenic types 16 and 18 may lead to some head and neck, anal, or penile cancers. The incidence of each of these cancers has increased worldwide in the past two decades, and HPV causes $5 \%$ of all human cancers.

Since September 2008 a free vaccination programme has been available for 12-13 year old girls in the United Kingdom, with a catch-up programme to vaccinate girls aged up to 18. Australia, the United States, two Canadian provinces, and Austria have introduced vaccination for boys as well as girls. And now the UK's Joint Committee on Vaccination and Immunisation, an advisory committee of the Department of Health, is investigating whether to extend the HPV vaccination programme to boys (see www.gov.uk/government/groups/joint-committee-onvaccination-and-immunisation). The cost effectiveness of the vaccine is a key consideration.

HPV related disease in men causes a considerable burden; therefore, vaccinating boys is likely to produce more health and economic benefits than those from a girls-only programme. A study of 4065 males aged 16-26 found that the quadrivalent HPV vaccine prevented genital warts and penile and anal cancer. ${ }^{1}$ And a meta-analysis of 22 studies (including 8360 men) examining men's attitudes and acceptance regarding HPV vaccination found a moderate level of acceptance in this population. $^{2}$

Various mathematical models have estimated the potential impact of a male vaccination programme, and its cost effectiveness is debated. Many models do not support the inclusion of men, but specifically men who have sex with men (MSM) are often excluded, and the focus is largely on the effect of the vaccine in terms of cervical cancer outcomes and not on predicting its effect on other cancers related to HPV. ${ }^{3}$ A recent Norwegian study considered all HPV related diseases and extending the programme to boys. It concluded that, although it might be cost effective to include boys, increasing the coverage in girls was uniformly more effective and cost effective.

If uptake is low in girls, the benefit of vaccinating boys is easily apparent. However, with high uptake in girls, vaccinating both sexes is less cost effective. Nevertheless, a European study that assessed male vaccination and all HPV carcinomas showed that vaccinating 12 year old boys and girls would be associated with substantial additional clinical benefits-namely, reduced incidence of HPV related genital warts and carcinomas, compared with vaccinating only girls. ${ }^{3}$ This additional benefit was noted even with an overall coverage of only $70 \%$. In addition, a two dose schedule (in place of the current three dose schedule) will be introduced in the UK in September ${ }^{5}$; this will increase the cost effectiveness of a vaccinating boys as well as girls.

Although the UK's vaccination programme reaches more than $80 \%$ of girls, many communities have much lower coverage rates: in half of London's primary care trust areas less than $80 \%$ of girls are vaccinated ${ }^{6}$; and a University College London study found that uptake was lower among minority ethnic groups. ${ }^{7}$

Concerns are also growing that some new "academy" schools may not accommodate school nurses and vaccination programmes. ${ }^{8}$ Uptake may also be low for boys in these groups, but vaccinating them would help to protect the girls. Boys themselves would be protected from acquiring HPV infection from non-vaccinated women and from other men.

The current girls-only vaccination programme leaves MSM at particular risk of infection because they do not benefit from any herd protection. Indeed, a programme targeted at MSM in the UK may be the most effective; its benefit may be limited, however, because many MSM acquire HPV as teenagers ${ }^{9}$ and may have been exposed to HPV already.

As for men who have sex with women, the extent to which they benefit from a girls-only vaccination programme even with a high uptake may also be limited. For example, in Denmark HPV 
vaccination has significantly reduced the incidence of genital warts among women but not among men. ${ }^{10}$

The suffering caused by HPV related diseases is self evident. The economic costs are also considerable: a study of treating nine major HPV related diseases in Italy produced an estimate of almost $€ 530 \mathrm{~m}(£ 420 \mathrm{~m}$; $\$ 714 \mathrm{~m})$ a year. ${ }^{11}$ And the cost of treating genital warts was almost $£ 17 \mathrm{~m}$ in England in $2008 .{ }^{12}$

Ultimately, any decision about whether to vaccinate boys should not be based solely on cost effectiveness. Public health, equity, and the human costs of HPV related disease for both sexes must be the main considerations.

Competing interests: I have read and understood the BMJ policy on declaration of interests and declare the following interests: I am a member of HPVAction.org.

thebmj.com Editorial: HPV vaccination (BMJ 2014;349:g4783, doi:10. 1136/bmj.g4783)

Provenance and peer review: Not commissioned; externally peer reviewed.

Giuliano AR, Palefsky JM, Goldstone S, Moreira ED, Penny ME, Aranda C, et al. Efficacy of quadrivalent $\mathrm{HPV}$ vaccine against $\mathrm{HPV}$ infection and disease in males. $N$ Engl $J$ Med 2011;364:401-11.
2 Newman PA, Logie $\mathrm{CH}$, Doukas N, Asakura K. HPV vaccine acceptability among men: a systematic review and meta-analysis. Sex Transm Infect 2013;89:568-74.

3 Marty R, Roze S, Bresse X, Largeron N, Smith-Palmer J. Estimating the clinical benefits of vaccinating boys and girls against HPV related diseases in Europe. BMC Cancer 2013;13:10.

4 Burger EA, Sy S, Nygård M, Kristiansen IS, Kim JJ. Prevention of HPV related cancers in Norway: cost effectiveness of expanding the HPV vaccination program to include pre-adolescent boys. PLoS One 201420;9:e89974.

5 Public Health England. HPV vaccination programme schedule changing from 3 to 2 doses. 14 May 2014. www.gov.uk/government/news/hpv-vaccination-programme-schedulechanging-from-3-to-2-doses.

6 Public Health England. Annual HPV vaccine coverage 2012 to 2013: by PCT and SHA. 16 December 2013. www.gov.uk/government/publications/annual-hpv-vaccine-coverage2012-to-2013-by-pct-and-sha.

7 Bowyer HL, Foster AS, Marlow LA, Waller J. Predicting human papillomavirus vaccination behaviour among adolescent girls in England: results from a prospective survey. $J$ Fam Plann Reprod Health Care 2014;40:14-22.

8 Boyle T, Holmes A. Persistence and partnerships: school nurses, inequalities and the HPV vaccination programme. Br J School Nurs 2013;8:71-7.

9 Zou H, Tabrizi SN, Grulich AE, Garland SM, Hocking JS, Bradshaw CS, et al. Early acquisition of anogenital human papillomavirus among teenage men who have sex with men. $J$ Infect Dis 2014;209:642-51.

10 Baandrup L, Blomberg M, Dehlendorff C, Sand C, Andersen KK, Kjaer SK. Significant decrease in the incidence of genital warts in young Danish women after implementation of a national human papillomavirus vaccination program. Sex Transm Dis 2013:40:130-5.

11 Baio G, Capone A, Marcellusi A, Mennini FS, Favato G. Economic burden of human papillomavirus related diseases in Italy. PLoS One 2012;7:e49699.

12 Desai S, Wetten S, Woodhall SC, Peters L, Hughes G, Soldon K. Genital warts and cost of care in England. Sex Transm Infect 2011;87:464-8.

Cite this as: BMJ 2014;349:94834

(C) BMJ Publishing Group Ltd 2014 